\title{
Building-integrated photo-voltaics: market challenges and bioinspired solutions
}

\author{
F. Klysner, Nicoline ; Lenau, Torben Anker; Lakhtakia, Akhlesh
}

Published in:

Bioinspiration, Biomimetics, and Bioreplication XI

Link to article, DOI:

$10.1117 / 12.2583504$

Publication date:

2021

Document Version

Publisher's PDF, also known as Version of record

Link back to DTU Orbit

Citation (APA):

F. Klysner, N., Lenau, T. A., \& Lakhtakia, A. (2021). Building-integrated photo-voltaics: market challenges and bioinspired solutions. In A. Lakhtakia, M. Knez, \& R. J. Martín-Palma (Eds.), Bioinspiration, Biomimetics, and Bioreplication XI: Proceedings of SPIE (Vol. 11586). [115860C] SPIE - International Society for Optical Engineering. https://doi.org/10.1117/12.2583504

\section{General rights}

Copyright and moral rights for the publications made accessible in the public portal are retained by the authors and/or other copyright owners and it is a condition of accessing publications that users recognise and abide by the legal requirements associated with these rights.

- Users may download and print one copy of any publication from the public portal for the purpose of private study or research.

- You may not further distribute the material or use it for any profit-making activity or commercial gain

- You may freely distribute the URL identifying the publication in the public portal 


\section{Building-integrated photo-voltaics: market challenges and bioinspired solutions}

Klysner, Nicoline, Lenau, Torben, Lakhtakia, Akhlesh

Nicoline F. Klysner, Torben A. Lenau, Akhlesh Lakhtakia, "Building-integrated photo-voltaics: market challenges and bioinspired solutions," Proc. SPIE 11586, Bioinspiration, Biomimetics, and Bioreplication XI, 115860C (22 March 2021); doi: 10.1117/12.2583504

SPE. Event: SPIE Smart Structures + Nondestructive Evaluation, 2021, Online Only 


\title{
Building-integrated photo-voltaics: Market challenges and bioinspired solutions
}

\author{
Nicoline F. Klysner, ${ }^{a}$ Torben A. Lenau, ${ }^{a,}{ }^{*}$ Akhlesh Lakhtakia ${ }^{\mathrm{b}}$
}

${ }^{a}$ Technical University of Denmark, Department of Mechanical Engineering, DK2800 Kgs. Lyngby, Denmark; ${ }^{b}$ The Pennsylvania State University, Department of Engineering Science and Mechanics, University Park, PA 16802, USA

\begin{abstract}
We have heavily relied for a few centuries on fossil fuels, which are basically dead plant material that was sequestered and converted millions of years ago, but the rapidly increasing energy demand combined with climatic challenges means we need to develop a large-scale supply of energy from sources without climatic impact. An obvious choice is to use solar energy directly when possible, and a complete global transition to solar energy by 2050 is realistic and cost effective. However, in order to find space for the large areas needed for harvesting solar energy by photovoltaic means, it would be advantageous if solar panels could be incorporated into urban buildings and free land for other uses. We undertook an analysis of the needs and requirements from the building industry that will allow for a more widespread use of solar panels on buildings, also referred to as Building Integrated Photo-Voltaics. Specifications and options for the visual incorporation of the solar panels in the building envelope were identified. Special attention was paid to (i) the role of modularization and standardization in architecture and (ii) the role of color and reflectance. A standardized mounting system is proposed that will allow for modular attachment of solar panels, making it easy to adjust, repair, and replace individual panels. Biological inspiration can be used to improve the system further. The forced-air ventilation of the tunnels of prairie dogs shows how to enhance cooling. The non-iridescent wings of butterflies of the Morpho genus, proposes how a low-cost structurally colored film can be inserted into the solar panel during its assembly.
\end{abstract}

Keywords: Aesthetics, biologically inspired design, photovoltaics, solar cells, urban use

\section{INTRODUCTION}

The global energy demand continues to rise, mainly due to population increase and the economic growth of developing countries. Today, $85 \%$ of the energy requirements are fulfilled by burning fossil fuels such as oil, coal, and natural gas. However, energy security, degradation of air quality, and the greenhouse effect are major concerns for the sustainability of human and other life forms.

The generation of energy from renewable resources such as the sun, wind, and biomass is promising, even essential, for the creation of more sustainable societies. The most promising non-polluting source of energy is the Sun. Solar energy falling on the Earth in one hour is more than the global energy consumption in one year. With rapid reduction in the cost of photovoltaic solar cells, solar energy can alleviate all three major concerns. Indeed, photovoltaic solar cells contributed to about $1.7 \%$ of the global electricity production in 2017 , and that share continues to grow.

The traditional way of applying solar panels to a building is referred to as Building Applied Photo-Voltaics (BAPV), the panels being mounted on top of existing building structures such as roof or façades. The proponents of Building-Integrated Photo-Voltaics (BIPV), on the other hand, advocate the incorporation of photovoltaics technology into building components, potentially resulting in economic gain, space savings and higher aesthetic quality. BIPV thus replaces existing building components like roof tiles and façade plates. Although the BIPV concept has existed for several years, it has not been reduced to common practice in building construction.

This paper begins with a description of the state of the art for BIPV. This is followed by results from an investigation whereby barriers and opportunities for increased use of BIPV were identified and the needs described. Finally, a modular mounting solution is presented which considers needs and selected barriers. The empirical evidence for this paper stems from literature research, internet research, and qualitative semi-structured interviews with selected stakeholders. The

Bioinspiration, Biomimetics, and Bioreplication XI, edited by Akhlesh Lakhtakia, Mato Knez, Raúl J. Martín-Palma, Proc. of SPIE Vol. 11586, 115860C · @ 2021 SPIE · CCC code: 0277-786X/21/\$21 · doi: 10.1117/12.2583504 
interviews and research was made in the Fall 2020 semester at the Technical University of Denmark as part of a final master thesis project. ${ }^{1}$

\section{STATE OF THE ART}

State of the art for BIPV in Denmark was researched with respect to available commercial BIPV products on the Danish market, the type of mounting system, and the coloring technique. Mounting and coloring are key components in achieving aesthetically acceptable BIPV.

\subsection{Structural integration and mounting systems}

As BIPV projects are generally considered pilot projects, often there are no standardized and complete solutions for structural integration in place for BIPV products. This means that many projects start from scratch by defining the acceptable mounting systems. Ways to fill out corners and edges have also not been made standardized. Although BIPV elements are integral parts of the building envelope by definition, these elements are often mounted as add-on decorative elements. This might be caused by a late integration of BIPV in the architectural and construction planning, thereby necessitating the use of customized mounting systems and thus raising the project cost. When PV panels are applied solely for aesthetic reasons, the savings from replacing other façade elements are lost.
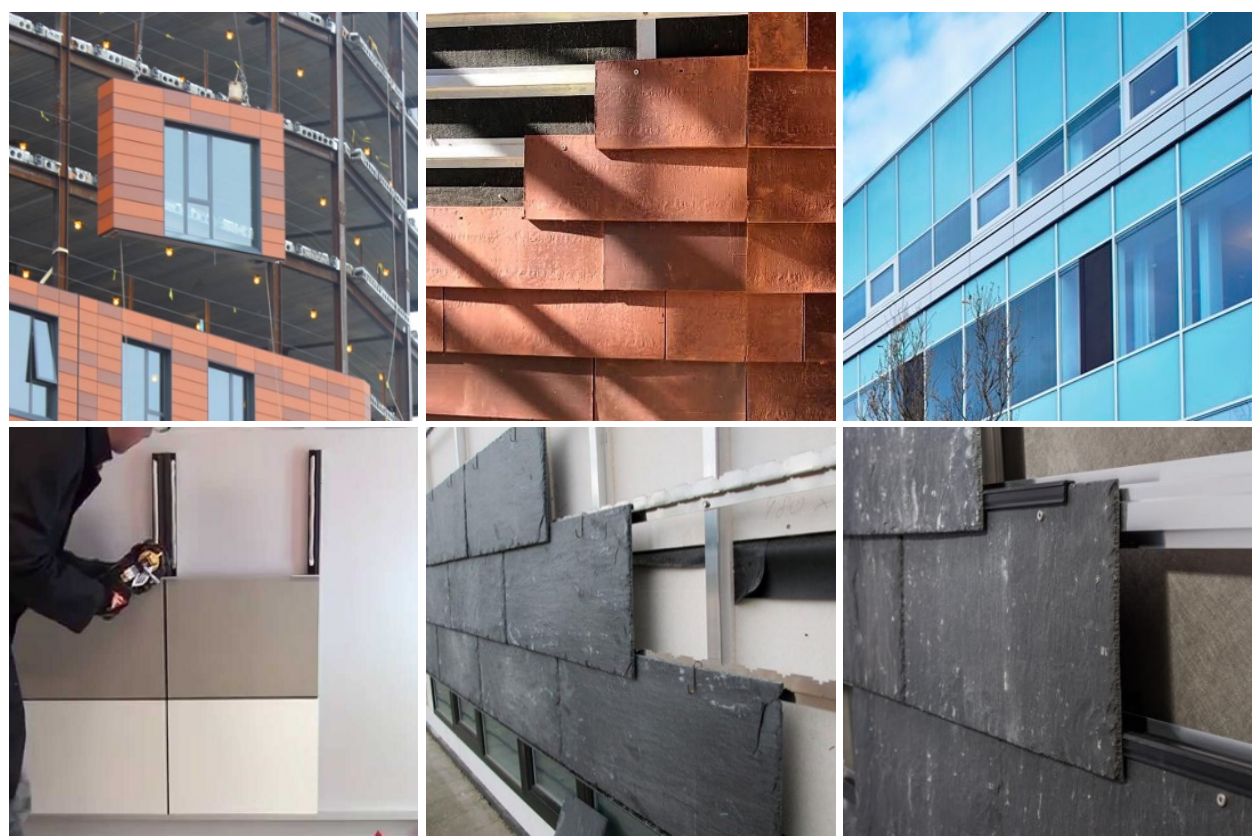

Figure 1. Top row: Existing mounting systems (from left to right): prefabricated façade system (CSR), ${ }^{2}$ ventilated façade system (Komproment), ${ }^{3}$ and curtain wall (HSHansen). ${ }^{4}$ Bottom row (from left to right): Mounting methods for ventilated façade panels (from left to right): Sikatack panelsystem, ${ }^{5}$ Komproment, ${ }^{3}$ and Komproment. ${ }^{3}$

Common ways to mount façade panels are with prefabricated façade systems, ventilated façade systems and curtain walls. In prefabricated façade systems, the panels are mounted in a metal frame or as decorative elements. In ventilated façade systems, the panels are mounted on a metal or wooden structure on top of the load bearing wall. Several ways exist for mounting the panels to the substructure. For curtain walls the panels are also mounted in metal frames. Figure 1 illustrates the two different façade systems and the different ways for mounting façade panels.

\subsection{Solar-panel coloring techniques}

Colors can be created with pigments ${ }^{6}$ or with structural coloring. ${ }^{7}$ A pigment absorbs some portions of the electromagnetic spectrum visible to humans and reflects the remainder of that spectrum. Structural coloring lets some portions of the visible spectrum to pass through but reflects the remainder. This characteristic makes structural color promising for colored solar cells. The perceived color of an object is determined by the wavelengths in the reflected light (chromaticity) and the amount of reflected light (brightness). ${ }^{8}$ To create the perception of color, a part of the visible spectrum from the sun is reflected. 
The reflected energy does not enter the solar cell and the efficiency of the solar panel is therefore reduced. ${ }^{9}$ The question thus becomes how to obtain aesthetically pleasing colors for solar panels without losing too much efficiency.

Different methods of coloring can be difficult to compare, since the colors produced by the different methods are not the same and thus the theoretical limit for efficiency is not the same either. ${ }^{9}$ Coloring methods suitable for opaque solar panels can be divided into the following three broad categories (adopted and modified from Eder et $_{\text {al. }}{ }^{6}$ ), as illustrated in Fig. 2.

- Anti-reflection (AR) coating on top of the solar cell. The color is varied by modifying the thickness of an AR coating of silicon nitride on top of the solar cell. Depending on the color, the efficiency decreases by $14-50 \%{ }^{10}$

- Interlayer. A colored film can be integrated in the solar panel as an extra layer between the cover glass and the solar cell ${ }^{8}$. The interlayer can be either a film with a special ink print or a structurally colored film. The efficiency reduction is dependent on the type of interlayer and the printing ink (if used). The efficiency loss is potentially below $10 \%$ for structurally colored film. ${ }^{8}$ The efficiency loss is higher with inks; e.g., $40 \%$ with a filter designed to provide a white appearance. ${ }^{8}$

- Modified cover glass. Either colored glass is used as the cover glass or a colored surface treatment is applied to the transparent cover glass. The efficiency loss range from below $20 \%$ to $40 \%{ }^{8}$
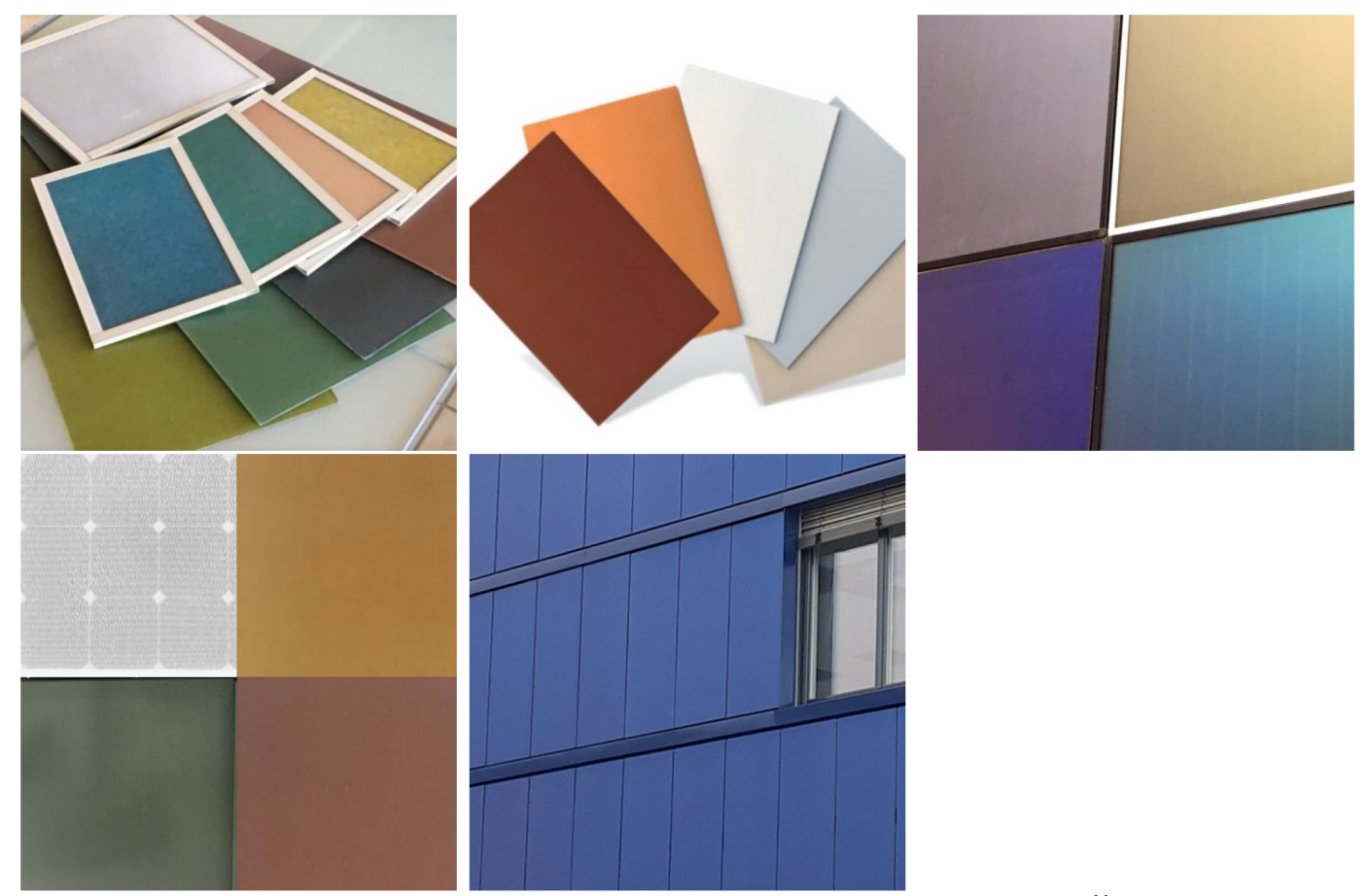

Figure 2. Examples of colored solar panels. Top row (from left to right): CFR Energy panels ${ }^{11}$ using unknown coloring technology, Solaxess panels ${ }^{12}$ colored with an interlayer, and Kromatix panels ${ }^{13}$ colored with a modified cover glass. Bottom row (from left to right): Racell panels ${ }^{14}$ using different coloring methods (AR coating, interlater, and modified cover glass) and Avancis ${ }^{15}$ using Kromatix panels. ${ }^{13}$

\subsection{Solar-panel efficiency}

A recent report estimates that it is possible to replace fossil energy with renewable resources by 2050 where solar energy plays the dominant role. ${ }^{16}$ To save precious land area that can be used for other purposes, many solar panels can be placed on buildings. However, it is important to ensure a high efficiency in electricity production to keep the area needed for solar panels low. Placing solar panels at non-optimal angles, applying color, designing backside ventilation, and the internal efficiency of the solar cell are all parameters that together define the efficiency of the solar panel. Tables 1 and 2 showcase the impact of these variables on the energy production and the needed solar cell area. The estimates are based on the following assumptions. The sun irradiates about $1000 \mathrm{~W} / \mathrm{m}^{2}{ }^{17}$ A silicon solar panel has an efficiency of $15-22 \% .{ }^{17}$ The 
specific yield is annually approximately $920 \mathrm{kWh}$ per $\mathrm{kWp}$ (kiloWatt peak) installed in Denmark. ${ }^{18}$ A 6-kWp plant can produce $6 \mathrm{kWh}$ under standard test conditions and full radiation.

Table 1 shows the output change and Table 2 the change in the needed area for (i) the best case and (ii) the worst case for roof- and façade-mounted PV solutions. The efficiency loss from color is $40 \%$ for the worst case and $10 \%$ for the best case. In comparison, the ventilation loss is $5 \%$ for the worst-case BIPV ${ }^{19}$ and no loss is assumed for the best-case BIPV and the best-case BAPV. The façade solution loses $21 \%$ efficiency compared to the roof solution, ${ }^{20}$ when both installations are assumed to be facing south. As a reference, a single-family household has an electricity consumption about 3000-4000 $\mathrm{kWh} / \mathrm{yr}^{17}$ and a $6 \mathrm{kWp}$-plant produces approximately $5520 \mathrm{kWh} / \mathrm{year}$.

Table 1. Output comparison for $40-\mathrm{m}^{2}$ photovoltaic plants [kWh/year].

\begin{tabular}{l|c|c|c|c} 
& Roof worst & Roof best & Facade worst & Facade best \\
\hline Effect BAPV no color $40 \mathrm{~m}^{\wedge} 2$ & 5520 & 8096 & 4361 & 6396 \\
\hline Effect BIPV no color 40 m² & 5244 & 8096 & 4143 & 6396 \\
\hline Effect BIPV color 40m^2 & 3146 & 7286 & 2486 & 5756
\end{tabular}

Table 2. Area comparison for $6 \mathrm{kWp}$ photovoltaic plants $\left[\mathrm{m}^{2}\right]$.

\begin{tabular}{l|c|c|c|c} 
& Roof worst & Roof best & Facade worst & Facade best \\
\hline Area BAPV no color 6kWp & 40 & 27 & 53 & 35 \\
\hline Area BIPV no color 6kWp & 42 & 27 & 51 & 35 \\
\hline Area BIPV color 6kWp & 70 & 30 & 89 & 38
\end{tabular}

\subsection{Manufacturing issues}

Variations in size, color, and mounting solution of solar panels are effected during the manufacturing process. The techniques selected to create variations have impacts on the investment in components (e.g., different types of cover glass) and the throughput time for the production of the panels. The steps in BIPV manufacturing include: first, the adjustment of the individual components; second, the assembly of the panel by gluing the layers in a sandwich structure; and third, the application of the mounting solution to the panel.

Coloring by coating the solar cells or by modifying the cover glass needs to be done prior to the assembly of the panel. The use of colored interlayers means that the variation creation can be done later in the assembly process. As it is not easy to adjust the size of the panels after they have been assembled due to the sensitive electronic components used, the size needs to be adjusted before final assembly. This aspect of BIPV is different from other building-envelope components, which often can be cut to size on site as needed. Likewise, coloring is not readily changeable for BIPV as for other types of façades (e.g., a wooden façade).

\subsection{System considerations}

Two support schemes have aided the implementation of photovoltaic technology in Denmark: yearly net metering (YNM) and feed-in-tariffs (FIT). With YNM, the grid practically become an energy-storage facility for the solar-plant owner. If a solar-plant owner delivers $1 \mathrm{kWh}$ to the grid, that person can use $1 \mathrm{kWh}$ from the grid at any given time within that year. Danish legislation enabling YNM was passed in 1993 and subsequently caused a great increase in installed capacity, especially in $2012(407 \mathrm{MW}){ }^{21}$ Now momentary net metering is used, which means that energy should be used right away to count as self-consumption. FITs are used to increase the market by ensuring a fixed price for the excess electricity sold to the grid. ${ }^{16}$ The FIT is different depending on when the solar panels were installed and who owns them. The FIT is additionally limited to plants with a certain capacity and a certain amount of energy produced, with the rest sold at the spot price. ${ }^{16}$ The support schemes in place encourage ownership of BIPV products.

The energy produced from BIPV can either be consumed directly or sold to the electric grid. An advantage of using the electricity locally is the virtual elimination of transport loss, which is economically desirable. ${ }^{16}$ The energy produced should either be used right away or stored to ensure high self-consumption. Storage options are expensive, and it can be difficult to match consumption with sunny hours. The produced energy can be used for household appliances, e.g. washing 
machines, dish washers, coffee machines, stoves, lighting systems, hairdryers, vacuums consoles, and speakers. In office and business buildings, solar energy can be used for cash registers, lighting systems, speakers, surveillance, computers, cleaning machines, coffee machines, microwaves, electrical blinds, and ventilation. Systems that ensure higher energy consumption during sunny hours can enhance self-consumption. An example could be being able to time the dishwasher to start at midday, the washing machine an hour later, and boiling water in a thermos pot during the daytime for evening use. Office buildings and industrial installations can take advantage of being active during daytime, when it is easier to match consumption with the sunny hours of the day.

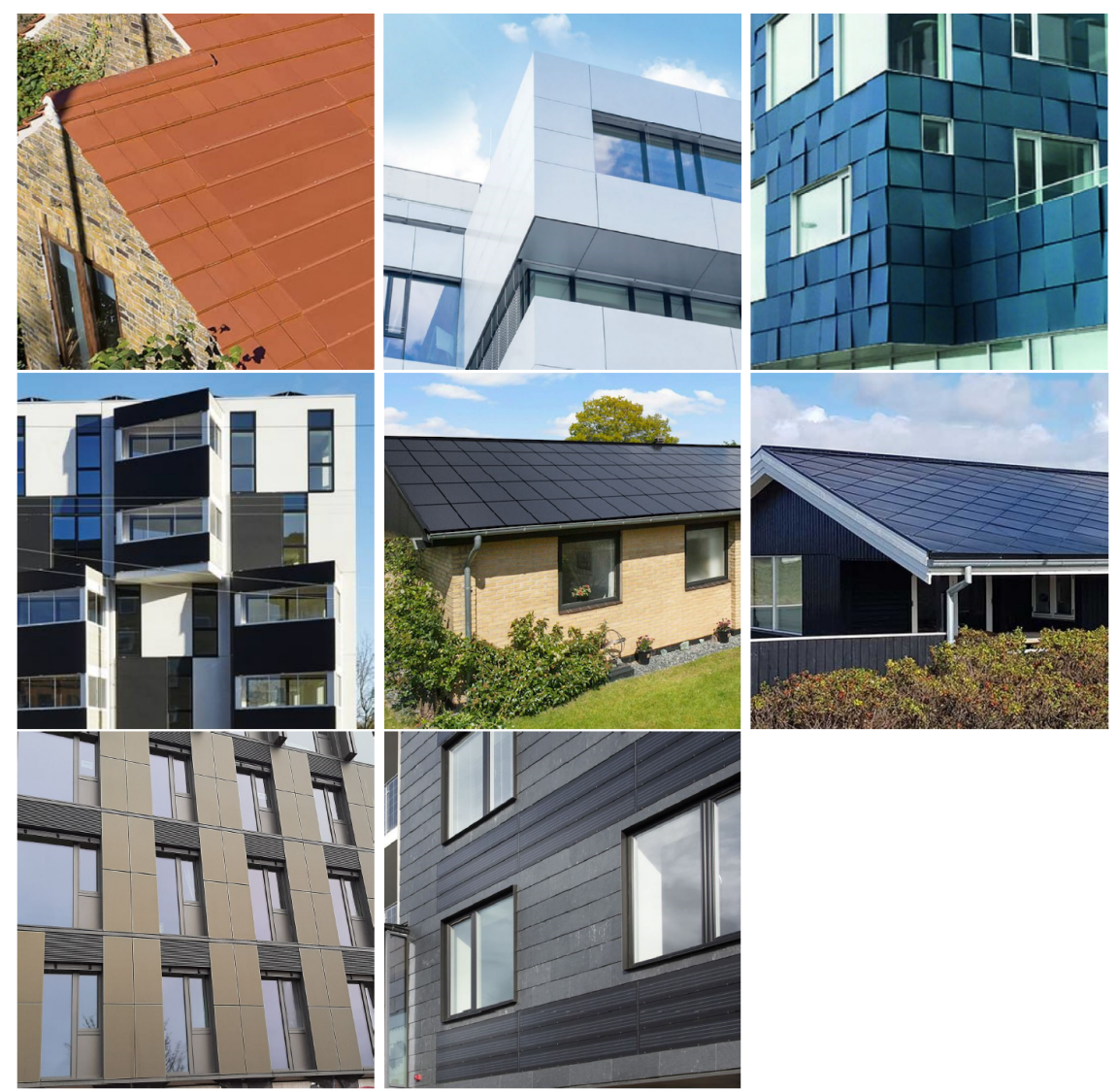

Figure 3. Examples of colored solar panels sold in Denmark. Top row (from left to right): CFR Energy panels, ${ }^{11}$ Solaxess façade panels, ${ }^{12}$ and Kromatix/SolarLab panels. ${ }^{13,22}$ Middle row (from left to right): Racell panels, ${ }^{14}$ Ennogie-taget panels, ${ }^{23}$ and an xsroof panel. ${ }^{24}$ Bottom row (from left to right): Skala panels ${ }^{15}$ and Zappa panels. ${ }^{25}$

\subsection{Existing BIPV products}

Several BIPV products are available on the Danish market. The following examples are meant to indicate the market status but do not constitute an exhaustive list of existing products or technologies on the market:

- CFR Energy Modules by Danish Solar Energy Ltd. ${ }^{11}$ Unknown coloring method, available in five standard colors: red, blue, grey and two green nuances.

- Solaxess façade by Solaxess. ${ }^{12}$ Colored film sold in six colors by Solar Partner. ${ }^{20 a}$

- Façade panels by SolarLab. ${ }^{22}$ Color treated glass, available in six colors (Kromatix by SwissINSO ${ }^{13}$ ).

- Façade panels by Racell. ${ }^{26}$ Colors and texture customizable. AR coatings, interlayer, and modified cover glass are used.

- Ennogie-taget by Ennogie. ${ }^{23}$ Available in black.

- T-roof, x-roof, and xs-roof by SolarTag. ${ }^{24}$ Available in black.

- Skala and PowerMax by Avancis Solar. ${ }^{15}$ Modified glass, available in eight colors (Kromatix by SwissINSO ${ }^{13}$ ) sold by Klimaenergi A/S. ${ }^{25 a}$

- Zappa and Linea by Komproment. ${ }^{25}$ Available in black. 
Examples of the products from the different manufacturers and suppliers are shown in Fig. 3. Some of the listed BIPV manufacturers describe means for mounting the panels. The façade BIPV panels mentioned are generally designed for use as façade cladding, specifically on ventilated façades in most cases. It can be assumed that ventilation is used to keep the panels cool, because they have an air gap behind the façade cladding.

\section{BARRIERS, OPPORTUNITIES, AND NEEDS}

The BIPV value chain illustrated in Figure 4 provides an overview of the involved stakeholders and their involvement with solar panels right from manufacture to maintenance. Arrows pointing from one stakeholder group to another indicate the impact of the first on the second. The interviewed stakeholders are marked on the map with numbers and the legend in the bottom of the illustration explains the types of stakeholders. Interviews were conducted with stakeholders from many different groups to ensure a broad perspective when identifying barriers, opportunities, and needs.

The following stakeholders were interviewed: (i) a BIPV manufacturer, (ii) two private BAPV owners, (iii) a BAPV installer, (iv) a municipality officer, (v) two building owners, (vi) an architect with experience in implementing solar panels in new and existing buildings, (vii) an officer of an interest organization for increased use of solar energy, and (viii) a façade entrepreneur. Numerous barriers and opportunities were found for employing BIPV as explained next, based on the interviews with these 10 actors belonging to eight different stakeholder groups from various parts of the value chain.

The identified barriers and opportunities are grouped into 5 overall topics: Structural integration and mounting, visual appearance, efficiency, manufacturing and system considerations. Although identified from the interviews, the barriers and opportunities were formulated and aggregated by the authors. Needs were formulated based on the interviews and a literature review.

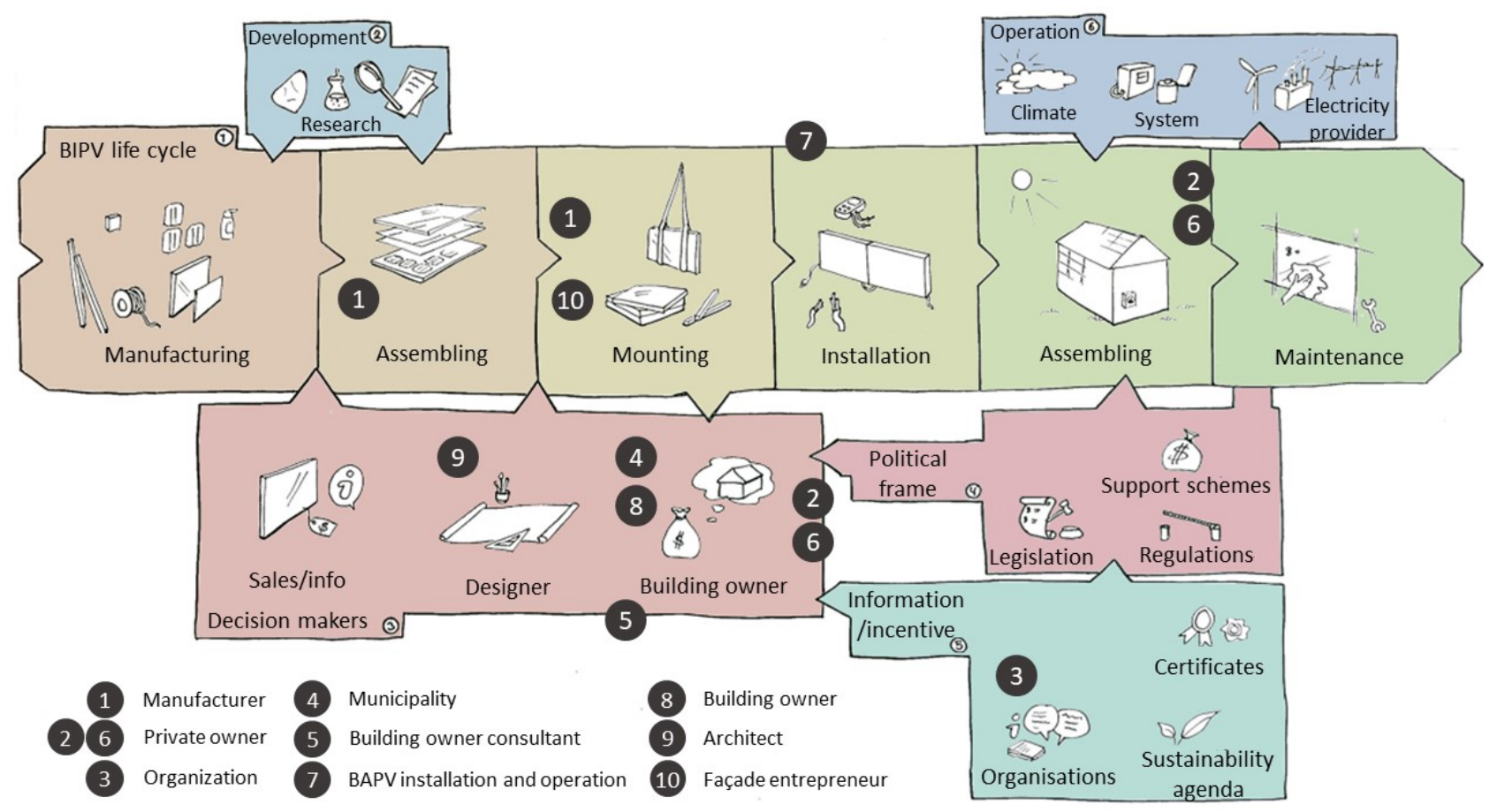

Figure 4. BIPV value chain and stakeholders.

\subsection{Structural integration and mounting systems}

Viewpoints on barriers from the stakeholders are described below. Each number inside a square bracket refers to the stakeholder group in Fig. 4.

- Information about the economics (efficiency) and mounting system for specific BIPV products is unavailable, which is a hindrance for decision makers. Lack of mounting information can be a barrier, because the entrepreneur 
cannot receive the information right away; then it is easier to choose an option with accessible information [9]. There is competition among the BIPV suppliers in Denmark as a fear of international competitors, which might influence the availability of information $[1,3]$.

- Insufficient knowledge exists about complex economics calculations. Without easy access to simple information about the economics of BIPV through, e.g., case studies [9] and reference houses [10], it is difficult to convince decision makers that BIPV is a good idea from an economical perspective. There is also a general lack of knowledge about available BIPV products [5].

- The number of issues to contend with when implementing BIPV is very high. What will the efficiency be if the solar panels are placed differently or colored differently? How can they be mounted? How will corners be filled? What is the cost and what is the gain? Which metering schemes and rules apply? $[3,4,9]$

- Lack of complete roof/façade fitting solutions makes it difficult to make nice transitions between different envelope elements and fitting the panels to various corners and transitions [4].

- Lack of (standard) mounting solution is sometimes a result of late integration or of the project being a showcase project [3]. Indeed, many BIPV projects start from scratch with the mounting system [4]. Lack of a solution for, or information on, mounting can be a barrier for choosing BIPV [9]. Opportunities mentioned by the stakeholders included:

- Savings resulting from replacing façade components [1]; and

- Saving of space (e.g., agricultural land) to offset BIPV costs [9].

Literature confirms that an important need is the lack of a common and standardized solutions which allow for aesthetically acceptable mounting of BIPV products and their adaptation to fit odd corners. This need relates to aesthetics, economics, and the ease of choosing BIPV products for a building project. ${ }^{27,28}$ Furthermore, BIPV is defined as an integrated part of the building envelope. It seems that BIPV products are often mounted as decorative elements, commonly caused by a late integration of BIPV in the architectural and construction planning of the building. When photovoltaic panels are applied solely for aesthetic reasons, the savings from replacing other façade elements are lost.

The mounting of BIPV products introduces specific requirements for ventilation, wiring, and maintenance. The panels need to be ventilated on both sides since they generate heat which lowers the electricity production efficiency. The panels also have electrical installations which needs to be managed and organized during the mounting operation. Furthermore, the mounting system should allow for maintenance, replacement, and refurbishment or redeployment to ensure the overall efficiency of the system, the aesthetics, and the circular economy of the solar panels. As the solar panels have fragile components, mounting should ensure protection, in particular, from moisture. These issues must be considered when deciding/designing a mounting solution.

\subsection{Visual appearance}

Barriers mentioned by the stakeholders are as follows:

- aesthetic unpleasantness which results from the building component hosting the solar panel(s) being visually mismatched from the solar panel(s) [4], and

- angle dependency of color is mostly unwelcome $[1,9]$.

Opportunities included aesthetic attractiveness $[2,9]$.

Needs concerning visual appearance relate not only to a single solar panel or other building components but also to the interplay between several different aspects of the appearance of the building component hosting the solar panel(s). Accordingly, the general needs related to the aesthetics for $\mathrm{BIPV}^{8,29}$ include:

- avoidance of visible frames (or other mounting systems),

- avoidance of discomfort from reflections,

- visual integration with the appearance of surrounding building components,

- avoidance of angle-dependent colors (unless specifically desired),

- context-dependent discreet or neutral appearance,

- different colors that match the colors of existing building components, and

- a complete façade/roof solution reducing the need for differently looking elements. 
From an architectural point of view, it is important that the façade material provides opportunities for designing an interesting aesthetic experience [9]. This is very dependent on the variety of choices available for elements. The needs for variation include:

- different colors (in some cases, from the colors of existing building components), and

- panel shapes and sizes.

Shape, texture, patterns, and positioning (overlap and distance from the underlying wall/roof) can also provide variation for interesting aesthetic experiences but are not necessary.

Existing solutions meet some of the general needs and the need for variety. These solutions avoid visible frames. BIPV solutions that cover a complete façade avoid issues with aesthetically standing out from the surrounding building components. Integration of solar panels with surrounding materials can be tricky, the existing coloring methods typically being angle-dependent and/or causing significant loss of efficiency.

\subsection{Solar-panel efficiency}

Barriers:

- Expensive products and processes are barriers for implementing BIPV. Solar energy has become a lot cheaper through the years, but there is still an opinion, or at least a perception, that BIPV products are too expensive [9, 10]. The cost of implementing BIPV derives from the product as well as from implementing a largely customized process [3]. The payback period needs to be somewhere around 10 years for most customers to be interested; a 20 -year payback period is too long [5].

- Concern for efficiency loss is mainly for façade elements because of their locations in a building, but there is also a general unease about when BIPV is appropriate to include [9]. The concern for efficiency loss links to higher cost and life-cycle assessment (LCA), in that BIPV must be both a good investment and a sustainable choice [9]. Aesthetically pleasing BIPV products often have big efficiency losses due to coloring, which makes BIPV less attractive [2].

Opportunities:

- Increased building value [4].

- Less electricity loss in transport compared to the use of remote field-based plants [3].

\subsection{Manufacturing issues}

Barriers and opportunities:

- Being able to offer variations from a basic template is an opportunity to attract customers. However, more variety increases manufacturing and inventory costs [1].

\subsection{System considerations}

Barriers:

- BIPV is generally not on the agenda of the building industry in Denmark, when planning a construction project. Extant BIPV projects are considered pilot projects [5].

- Designing an aesthetically pleasing solution will directly mitigate other barriers such as aesthetic discordance, lack of (standard) mounting systems, and lack of adequate complete roof/façade fitting. Barriers such as higher cost and efficiency loss could also be considered in the design process, to reach visually and economically acceptable designs.

- LCA of building components is important when deciding between competing products [9]. Currently, LCA for BIPV does not look promising, as it is hobbled by historical assumptions about manufacturing locations and ignores the role of the source of energy used for manufacture, transport, deployment, maintenance, and eventual disposal $[3,9,11]$.

- Adoption of BIPV during the construction process becomes increasingly difficult as the project progresses [7, 9]. BIPV is often only included early on, if a person in the process is dedicated to including BIPV [3], but capacity limitations and governmental regulations can make it difficult to include BIPV early on [9].

- Legal barriers are caused by the legislation tied to being an electricity producer. The laws impact who can deploy and use BIPV products as well as the expenses and profits of owning solar panels. Changes in laws and regulations cause additional uncertainties $[2,3,4]$. 
- Lack of affordable energy storage has become a barrier for private households $[2,3,6,8]$ after the net metering was changed from yearly to hourly. High self-consumption is economically optimal under the current conditions; it would be highly facilitated by adequate energy-storage facilities ${ }^{16}$. The available options are perceived to be too expensive, thereby limiting investment in solar energy. For instance, a $13.5 \mathrm{kWh}$ Powerwall from Tesla cost $\$ 7,000$ + additional $\$ 1,000$ for supporting hardware. ${ }^{30} \mathrm{BYD}$ offers a variety of energy-storage options of which the one with a similar capacity to Tesla's battery $(12.8 \mathrm{kWh}) \operatorname{costs} \$ 7,700 .^{31}$ Both manufactures guarantee their product for 10 years.

\section{SUGGESTIONS FOR SURMOUNTING THE BARRIERS}

A mounting system for aesthetically pleasing solar panels is presented in the following sections. Naturally, no one-solutionfits-all system is feasible, since buildings vary both in construction and looks. The mounting solution presented here is designed for opaque panels mounted on ventilated façades on commercially owned buildings. Advantages of focusing on commercially owned buildings as opposed to private homes include the branding opportunity, the straightforward aesthetic compatibility, options for local use of produced electricity, and larger installation size. Even though façade-mounted BIPV has a lower efficiency than its roof-mounted equivalent, the former is economically more attractive. ${ }^{32}$ The economy in installing BIPV is highly impacted by the support schemes as well as the amount of self-consumption of the solar energy harvested. The full solution presented here is referred to as SolarFaçade and the brackets designed for mounting are referred to as SolarMounts.

\subsection{Inspiration}

The theoretical solutions for mounting and coloring were inspired by existing façade-mounting systems and the bioworld. The two sources of inspiration are briefly described next.

\subsection{Existing façades}

Different façade types were researched for opaque façade-mounted BIPV. Two appropriate types identified namely prefabricated façades and ventilated façades. For the proposed solution, ventilated façades were chosen because it is an energy efficient type of façade which provides the needed ventilation for the panels. Prefabricated façades offer other advantages such as being able to perform electrical installations while on the ground.

\subsection{Bioinspiration}

Another source of inspiration was how certain functional challenges related to the aforementioned barriers are overcome and the aforementioned opportunities are made use of in the bioworld. The ventilated façades represent one type of solution to unwanted production of thermal energy by solar panels (which reduces the electricity production efficiency). It was therefore relevant to investigate how similar problems are surmounted in biological organisms. ${ }^{33}$ This was done by searching for ways to cool without moisturization.

One way of cooling relies on convection whereby air gets warmer as it is streamed over a warm surface. This mechanism is seen in the nests of leaf cutting ants; wind forces air through channels in the nest and then exits the nest. ${ }^{34}$ Another solution is exhibited by the tunnels of prairie dogs. ${ }^{35}$ The openings to these tunnels are placed at different heights in the terrain; thanks to the chimney effect, lower pressure at the higher entrances results in airflow through the tunnels. Some animals such as the jackrabbit and the elephant have a large network of shallow blood veins in their ears for effective cooling of the blood. ${ }^{36}$

Another way of cooling is to transport energy through an evaporating liquid. Many mammals benefit from this mechanism when sweating; indeed, when a dog pants, it speeds up evaporation from the humid surfaces in its mouth. The same phenomenon is also seen within the plant kingdom in the perspiration from leaves which lowers their temperature. ${ }^{37}$

If air is used to cool heated solar panels, water can enter though openings. Several mechanisms for either keeping water out or removing moisture are exhibited in the bioworld. One mechanism is the formation of contiguous hydrophilic and hydrophobic areas on the bamboo leaf to channel water on the leaf surface. ${ }^{38}$ Another mechanism is found on the leaves of many tropical plants. ${ }^{39}$ Each leaf has a drip tip that efficiently runs water from the leaf and lets it dry quickly. Yet another mechanism involves a humidity-sensitive valve found in some desert flowers (e.g., Lupinus arboreus). ${ }^{40}$ These valves can 
control the humidity level within the plant to protects its seeds. The sandgrouse feathers utilize the capillary effect to lead moisture to the top surface of the feathers where it can evaporate. ${ }^{41,42}$

Another relevant issue is the coloration BIPV solar panels without restricting the unreflected part of the visible spectrum from reaching the semiconductor layers inside solar cells. Analogous selective-spectrum reflection is observed in many beetle species whose structurally colored exoskeletons are partially transparent for some colors; ${ }^{43}$ e.g., the golden beetle Apistomorpha tecta reflects golden color when alive but becomes brownish transparent after death. However, a challenge in using structural colors is the phenomenon of iridescence, i.e., a color shift depending on the viewing angle. Iridescence has been overcome in many butterfly species in the Morpho genus through the geometry of the color-generating structure. $^{44,45}$

\subsection{Structural integration}

Ventilated façades are appropriate for BIPV due to a ventilation gap between the outer layer and the load-bearing wall to ensure that the solar panels are kept cool. The panels on a ventilated façade are mounted on a metal or wooden substructure. The panels are not load bearing and a ventilation gap between the panels is allowed. A special mounting bracket named SolarMount was designed for fastening the panel to the substructure, as shown in Fig. 5. It allows for easy mounting, disassembly, and adjustments. The design shown is a first attempt, and further development would probably result in optimization of some larger aspects and several smaller details. There are two parts in the bracket: part A which is fastened to the substructure and part B which is mounted to the back side of the solar panel.

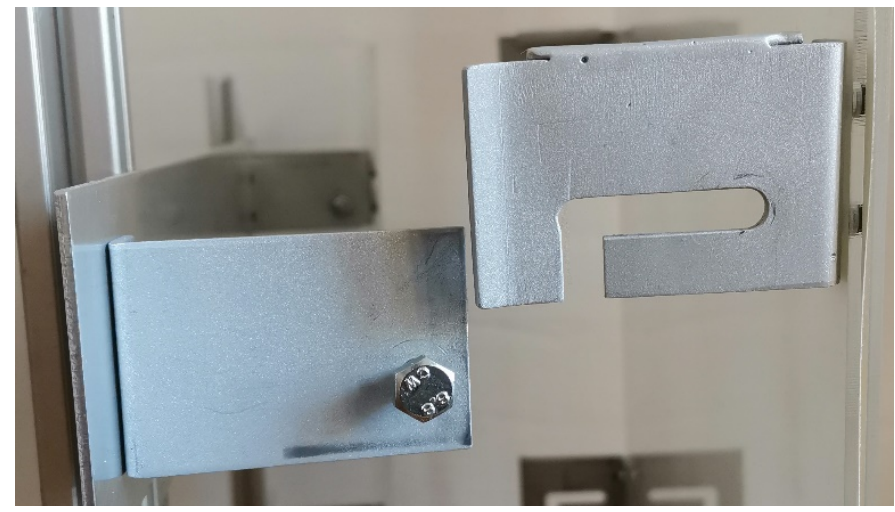

Figure 5. SolarMount bracket prototype for easy assembly, disassembly and adjustments. Part A is to left and part B to the right.

Means to fill out any corner or area on the façade have been included in the solution. These include having brackets with variations designed to fit adjacent panels, panels adjacent to other objects (e.g., windows), and corner panels; see Fig. 6. Not only solar panels, but panels for other purposes and even dummy panels can be accommodated.

Dummy panels looking the same as solar panels are useful in BIPV for several reasons. First, dummy panels can be used in areas where partial shadow frequently occurs. Second, dummy panels decouple area from capacity, allowing the building owner to use one solution for an entire façade without committing to a specific solar-energy generation capacity. Third, the dummy panels can be cut to fit odd spaces as shown in Fig. 7, because they do not contain electrical components. 

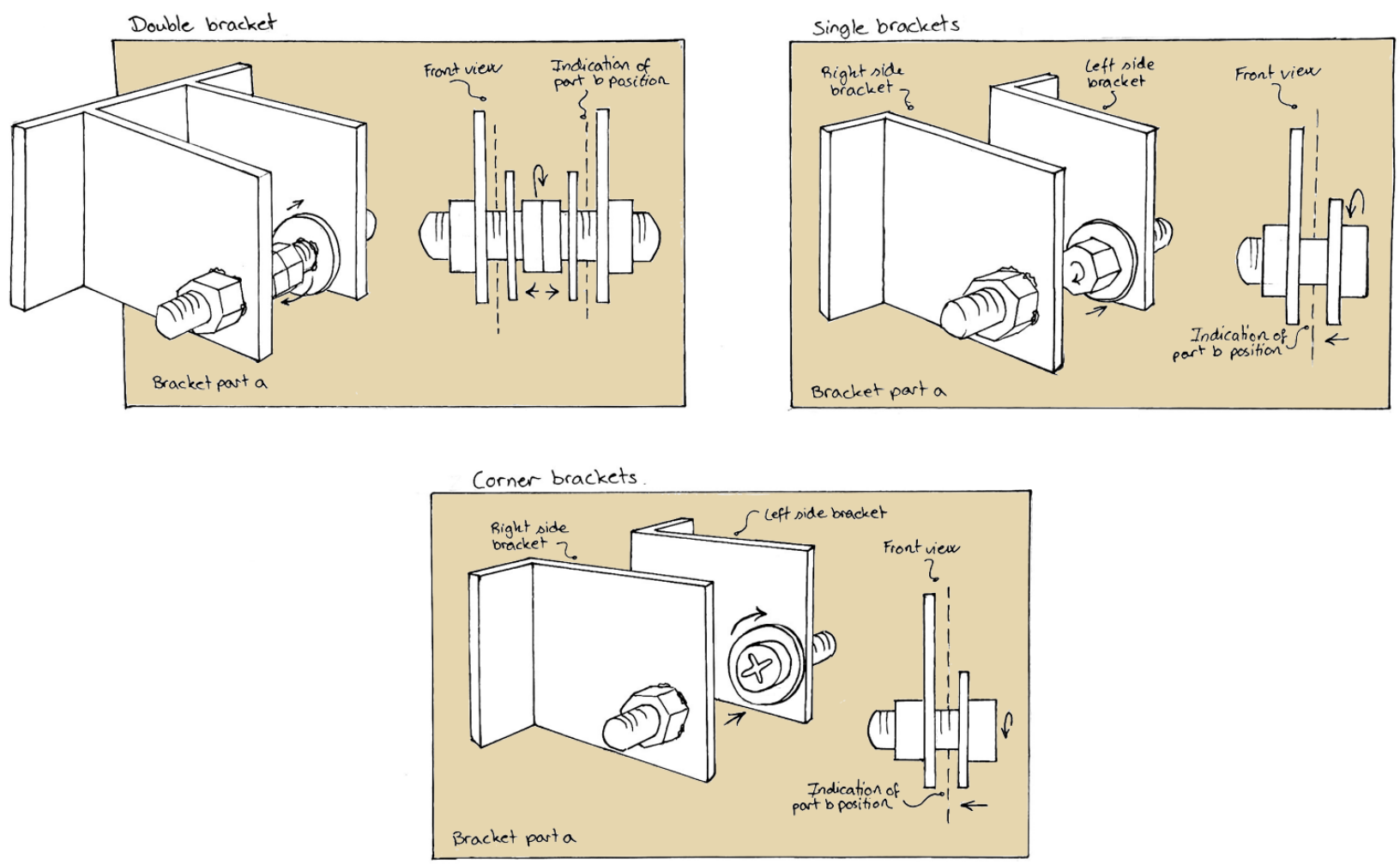

Figure 6. Variations for part A of SolarMount brackets. Top left: for adjacent panels; top right: for panels adjacent to other components (such as doors); and bottom: for corner panels.
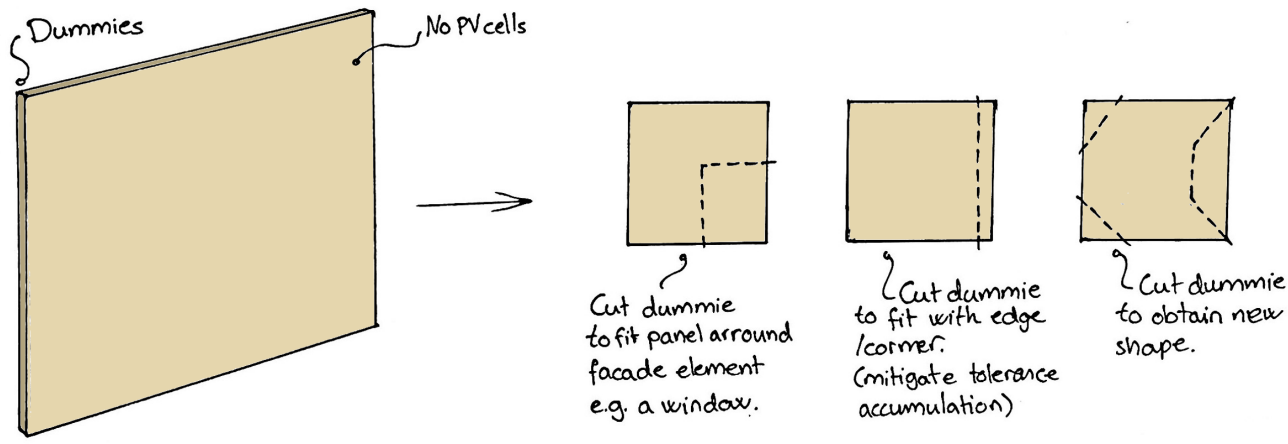

Figure 7. Dummy panels for residual areas with odd shapes.

\subsection{Mounting, maintenance, and repair}

The façade panels are mounted with a two-part bracket, one part fastened to the backside of the panel. The procedure for mounting is shown in Fig. 8 as follows: first, part A of the bracket is mounted on the substructure of the ventilated façade; second, the solar panel with part B of the bracket is lifted over part A; third, the bottom part of part B is rested on the bolt of part A; fourth, the panel is slid so that the grooves in part B are found and the panel falls into place. When the bolts are correctly mounted in the grooves, the panel can be be let go of. The panel then rests on the top hooks of primary brackets. The electrical installations are done, the panel is adjusted as necessary, and then all bolts are tightened to fasten the panel. The mounting procedure allows for easy dismounting of individual panels, as well as easy access to electrical installations, without having to lift the panel out completely. The system allows for different work procedures, whether the installations are done right away or after the panels has been mounted. The prototype has a $6-\mathrm{cm}$ ventilation gap on the backside of the 
panels. The ventilation gap would probably be $10-15 \mathrm{~cm}$ for larger solar panels. The gap between two adjacent panels is $1 \mathrm{~cm}$.
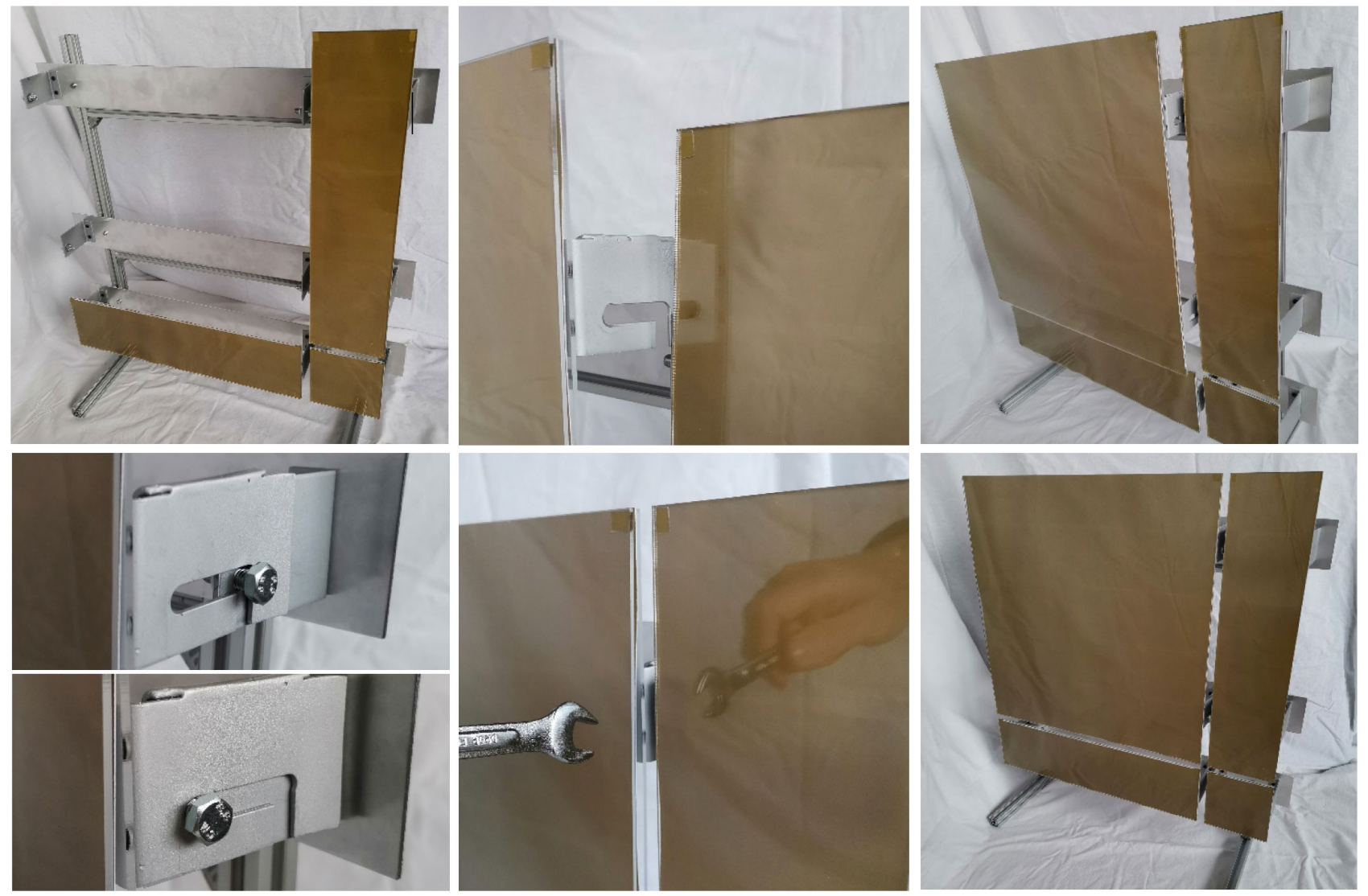

Figure 8. Mounting procedure for SolarFaçade.

\subsection{Visual appearance}

The proposed solution meets both general and variation needs. A clean aesthetic is provided with (i) no visible frames or mounting system, (ii) a full-façade solution, and (iii) the capability of adjustment to diverse requirements on shape, size, arrangement, and placement (i.e., depth, flatness and overlaps). Fig. 9 shows examples of how the modular BIPV panels can be combined. The solution assumes the use of a separate coloring technique integrated as an extra layer in the solar panel, which allows for considerable flexibility in choosing the color.

\subsection{Solar-panel efficiency}

The usual method to achieve a desired visual appearance and color is to apply pigments to the surfaces of building materials. However, application of pigments to the cover glass or a film placed inside a solar panel results in a significant loss of efficiency since pigments absorb most of the energy from the unreflected part of the visible spectrum. Structural colors, on the other hand, allow the unreflected light to reaching the semiconductor layers inside solar cells, wherein electricity is generated. ${ }^{29}$ Thus, structural colors are less detrimental than pigments to the efficiency of electricity production. Iridescence can be overcome by proper design of the color-generating structure. ${ }^{44,45}$

\subsection{Manufacturing issues}

Coloration of the solar panel should be implemented as late in the manufacturing process as possible, in order to customize color. This will minimize the needed stock. Implementing color as a foil laminated into the panel can be a way to obtain this. A structural-color film designed to suppress iridescence could therefore be an economically advantageous way to color BIPV. It will be advantageous for the solar-panel manufacturer to have a larger variety of differently colored films 
in stock, thus allowing a broad range of colors to be offered with fast delivery. The alternative would be to use colored glass which would increase investment in and storage of glass plates.

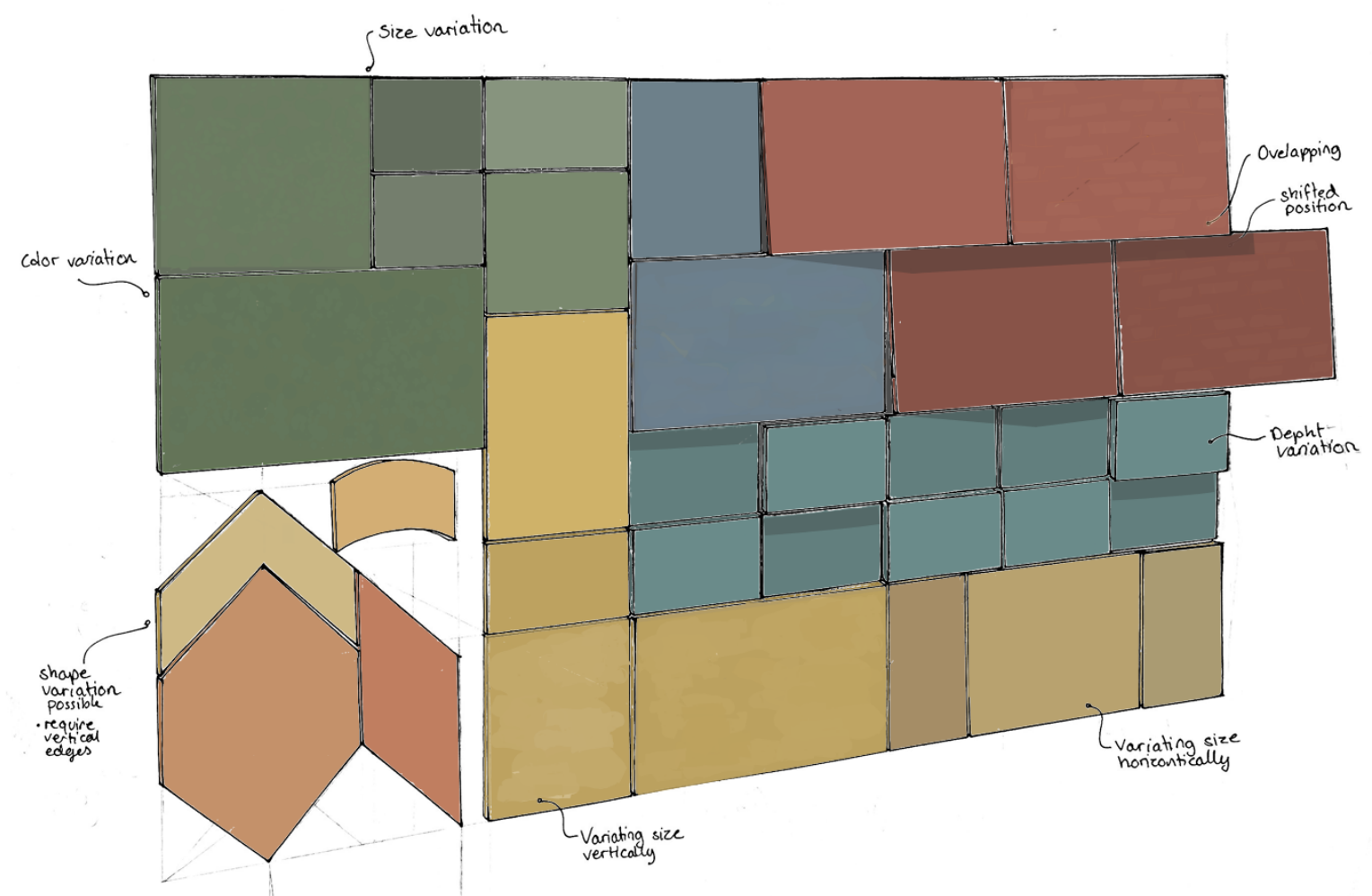

Figure 9. Examples of how modular BIPV panels can be combined

\section{DISCUSSION}

BIPV should be as easy to choose for a building envelope as any other component. For this to become reality, architects, financiers, and building owners should understand what the choice to include BIPV entails and how it can be implemented. What are the aesthetic opportunities? What is the economy? And how is it mounted? If there are no solutions for mounting readily available with detailed information, various parties in the decision-making process are unlikely to opt for BIPV.

With most other building-envelope components, it is easy to find existing buildings whose visual appearance can be assessed; in contrast, BIPV examples are rare. Likewise, there are many examples of how to mount slate, tile, stone, etc., but mounting systems for BIPV have to be developed almost de novo for a new project. It is easy to get inspiration and knowledge from one's surrounding when choosing something common.

Lastly, whereas the economics of non-active building envelope components is widely understood, BIPV is tricky because it creates profit and is therefore an investment. Every little inconvenience and uncertainty about selecting BIPV negatively impact the decision for incorporation of BIPV; hence, it is important to work towards the alleviation of those concerns. Only then will BIPV become an easy choice.

One way to alleviate those concerns is to standardize mounting systems. Standard solutions can provide a sense of security in the process of selecting BIPV and lower cost related to planning and mounting. The mounting system can be standardized to a certain extent, but issues such as the building's location and height as well as the tilt angles of its exterior walls will impact the requirements for an adequate mounting system. A standard mounting system should therefore be customizable to some extent. A standardized mounting system will mitigate aesthetic discordance, lower costs, and surmount the lack of complete roof/façade fitting solutions. Solar panels would thus be actually integrated in the building envelope with easy access for maintenance. 
The bioinspired SolarFaçade can contribute to the BIPV uptake by providing:

- a standard mounting solution (potentially),

- a full-façade solution without aesthetic discordance,

- access to electrical installations,

- repair and replacement of individual panels, and

- reduced efficiency loss (by using structural colors).

However, it has the following drawbacks:

- Transport is inconvenient due to bracket flaps on the panel.

- Mounting of the bracket parts requires precision, both when mounting part A on the substructure of a ventilated façade and when placing part B on part A.

- The incorporation of SolarFaçade is an additional step in the panel assembly process.

- Panels will only fit SolarMount if manufactured with SolarMount brackets

\section{CONCLUSION}

In this paper, we have described the present status for building-integrated photo-voltaic systems in Denmark, with possible extrapolation to the remainder of the European Union. Barriers and opportunities have been identified by interviewing selected stakeholders from all parts of the BIPV value chain.

A standardized mounting system will allow for modular attachment of solar panels, making it easy to adjust individual panels and to replace malfunctioning panels after the whole system has been mounted. The SolarFaçade mounting system allow backside cooling which can be further improved with biological inspiration from the forced-air ventilation of the tunnels of prairie dogs. For coloring of solar panels, we propose a low-cost structurally colored film that can be inserted into the solar panel during its assembly. The structural color will reduce the electricity production efficiency less than a pigment layer. Inspiration from the wings of butterflies of the Morpho genus will eliminate iridescence. We have thus proposed solutions to two of the barriers to BIPV so that they will be turned into opportunities.

\section{ACKNOWLEDGEMENT}

A. Lakhtakia thanks the US National Science Foundation (Grant No. DMS-2011996) and the Charles Godfrey Binder Endowment at the Pennsylvania State University. N. Klysner and T.A. Lenau are grateful to the participants in the Danish ColorFoil project who have supplied valuable guidance into the world of aesthetic solar panels.

\section{REFERENCES}

[1] Klysner, N. F., [Building-integrated solar panels An analysis and a design proposal], Master Thesis, Technical University of Denmark (2021).

[2] CSR, "Offsite and prefabricated buildings," $<$ https://www.csr.com.au/buildingsolutions/offsite-and-prefab $>(13$ February 2021 ).

[3] Komproment, "Facade," $<$ https://komproment.dk/da/facade/> (13 February 2021$).$

[4] HSHansen, "References," <http://www.hshansen.dk/dk/referencer> (13 February 2021$).$

[5] Sikatack, "Facade panel bonding," $<$ https://industry.sika.com/en/home/building-components/facade/panelcladding.html > (13 February 2021$)$.

[6] Eastaugh, N., Walsh, V., Chaplin, T., and Siddall, R., [Pigment Compendium], Routledge, New York, NY, USA (2013).

[7] Dushkina, N., and Lakhtakia, A., "Structural colors," in: Lakhtakia, A., and Martín-Palma, R. J., Eds.,[Engineered Biomimicry], Elsevier, Waltham, MA, USA (2013).

[8] Eder, G., Peharz, G., Trattnig, R., Bonomo, P., Saretta, E., Frontini, F., López, C. S. P., Wilson, H. R., Eisenlohr, J., Chivelet, N. M., Karlsson, S., Jakica, N., and Zanelli, A., [Report T15-07 - Coloured BIPV Market, Research and Development], IEA International Energy Agency (2019). <https://iea-pvps.org/key-topics/iea-pvps-15-r07coloured-bipv-report/> (13 February 2021).

[9] Halme, J., and Mäkinen, P., “Theoretical efficiency limits of ideal coloured opaque photovoltaics,” Energy 
Environ. Sci. 12(4), 1274-1285 (2019).

[10] Klampaftis, E., Ross, D., Kocher-Oberlehner, G., and Richards, B. S., "Integration of color and graphical design for photovoltaic modules using luminescent materials," IEEE J. Photovoltaics 5(2), 584-590 (2015).

[11] Danish Solar Energy, "Colored Sustainable Roofs and Facades - A Solar Revolution," $<$ https://danishsolarenergy.com/en/> (13 February 2021 ).

[12] Solaxess, "Portfolio photo photovoltaic," <https://www.solaxess.ch/en/portfolio/photo-photovoltaic-en/> (13 February 2021 ).

[13] SwissInso, "Kromatix ${ }^{\mathrm{TM}}$ by SwissINSO," $<$ https://www.swissinso.com/> (13 February 2021$)$.

[14] Racell, "Aesthetic options," $<$ http://racell.dk/products/aesthetic-options $>$ (13 February 2021$).$

[15] Avancis, "Our powerful CIS solar technology," <https://www.avancis.de/en/cigs-technology/> (13 February 2021 ).

[16] Mathiesen, B. V., David, A., Petersen, S. A., Sperling, K., Hansen, K., Nielsen, S., Lund, H., and Neves, J., [The Role of Photovoltaics towards 100 \% Renewable Energy Systems - Based on international market developments and Danish analysis], Aalborg University (2017).

[17] Mertens, K., [Photovoltaics - Fundamentals, Technology, and Practice], John Wiley \& Sons Ltd, Chichester, United Kingdom (2018).

[18] PA Energy ltd, [Large Scale PV Plants - Also in Denmark], PA Energy Ltd. (2011).

[19] Dyck-Madsen, S., and Bøndergaard, M. R., [Bygnings- integreret energiproduktion - kortlægning af det danske marked for bygningsintegrerede VE-løsninger til el- og varmeproduktion], Det Økologiske Råd Blegdamsvej 4B 2200 København N www.ecocouncil.dk (2011).

[20] Vind og Sol, "Solceller, CIS den nye generations tyndfilmsceller - VIND og SOL," $<$ http://www.vindogsol.dk/genecisfordele.html > (11 February 2021 ).

[20a] Solar Partner, "Solaxess Façade - Specialister på de lyse farver," < https://solarpartner.dk/solaxess-façade/> (13 February 2021).

[21] PA Energy, [Solceller - Dansk strategi for forskning, udvikling, demonstration], Energistyrelsen (2016).

[22] SolarLab, "Bespoke energy producing facades," $<$ https://solarlab.dk/> (13 February 2021$)$.

[23] Ennogie, "Sådan virker det," <https://ennogie.com/da/solcelletaget/> (13 February 2021 ).

[24] SolarTag, "Integreret solcelle tag med æstetik," <solartag.eu> (13 February 2021 ).

[25] Komproment, "Integrerede solceller," $<$ https://komproment.dk/da/facade?integrerede-solceller/> (13 February $2021)$.

[25a] KlimaEnergi, "Kommercielle solcelleanlæg -til erhverv, kommuner, regioner," $<$ https://klimaenergi.dk/solcellererhverv/> (13 February 2021).

[26] Racell, "Customised Solar Cells for Architecture," 2021, <https://racell.dk/> (12 February 2021 ).

[27] Corti, P., Bonomo, P., Frontini, F., Macé, P., and Bosch, E., "Building Integrated Photovoltaics : A practical handbook for solar buildings' stakeholders Status Report” (2020).

[28] The PVSITES Consortium, "BIPV market and stakeholder analysis and needs Project report" (2016).

[29] Lenau, T. A., Ahmad, F., and Lakhtakia, A., "Towards biomimetic red solar cells," Proc. SPIE 10965(1), 109650E (2019).

[30] Energysage, "Tesla Powerwall Home Battery Complete Review | EnergySage," $<$ https://news.energysage.com/tesla-powerwall-battery-complete-review/> (17 February 2021 ).

[31] Europe-Solar_Store, "BYD Battery-Box Premium HVS 12.8," <https://www.europesolarstore.com/batteries/manufacturer/byd.html> (17 February 2021 ).

[32] Gholami, H., and Røstvik, H. N., "Economic analysis of BIPV systems as a building envelope material for building skins in Europe," Energy 204, 117931 (2020).

[33] Lenau, T. A., and Lakhtakia, A., [Biologically Inspired Design: A Primer], Morgan \& Claypool, San Rafael, CA, USA (2021).

[34] Kleineidam, C., Ernst, R., and Roces, F., "Wind-induced ventilation of the giant nests of the leaf-cutting ant Atta vollenweideri," Naturwissenschaften 88(7), 301-305 (2001).

[35] Vogel, S., Ellington, C. P., and Kilgore, D. L., "Wind-induced ventilation of the burrow of the prairie-dog, Cynomys ludovicianus,” J. Comp. Physiol. 85(1), 1-14 (1973).

[36] Hill, R. W. ., and Veghte, J. H., "Jackrabbit Ears : Surface Temperatures and Vascular Responses," Science (80-. ). 194(4263), 436-438 (1976).

[37] Folk, G. E., and Semken, A., "The evolution of sweat glands," Int. J. Biometeorol. 35(3), 180-186 (1991).

[38] Wigzell, J. M., Racovita, R. C., Stentiford, B. G., Wilson, M., Harris, M. T., Fletcher, I. W., Mosquin, D. P. K., 
Justice, D., Beaumont, S. K., Jetter, R., and Badyal, J. P. S., "Smart water channelling through dual wettability by leaves of the bamboo Phyllostachys aurea," Colloids Surfaces A Physicochem. Eng. Asp. 506, 344-355 (2016).

[39] Ivey, C. T., and Desilva, N., “A test of the function of drip tips," Biotropica 33(1), 188-191 (2001).

[40] Hyde, E. O. C., "The function of the hilum in some papilionaceae in relation to the ripening of the seed and the permeability of the testa," Ann. Bot. 18(2), 241-256 (1954).

[41] Cade, T. J., and Maclean, G. L., "Transport of Water by Adult Sandgrouse to Their Young," Condor 69(4), 323343 (1967).

[42] Joubert, C. S. W., and Maclean, G. L., "The Structure of the Water-Holding Feathers of the Namaqua Sandgrouse," Zool. Africana 8(2), 141-152 (1973).

[43] Lenau, T., and Barfoed, M., "Colours and metallic sheen in beetle shells - A biomimetic search for material structuring principles causing light interference,” Adv. Eng. Mater. 10(4), 299-314 (2008).

[44] Saito, A., Murase, J., Yonezawa, M., Watanabe, H., Shibuya, T., Sasaki, M., Ninomiya, T., Noguchi, S., Akaikasaya, M., and Kuwahara, Y., "High-throghput reproduction of the Morpho butterfly's specific high contrast blue,” Proc. SPIE 8339(1), 83390C (2012).

[45] Chung, K., Yu, S., Heo, C.-J., Shim, J. W., Yang, S.-M., Han, M. G., Lee, H.-S., Jin, Y., Lee, S. Y., Park, N., and Shin, J. H., "Flexible, angle-independent, structural color reflectors inspired by morpho butterfly wings," Adv. Mater. 24(18), 2375-2379 (2012). 